\title{
Localization of Quantitative Trait Loci for Yield Components in a Cross Oriental $\times$ Occidental Barley Cultivar (Hordeum vulgare L.)
}

\author{
Mohammad SAMERI and Takao KOMATSUDA* \\ Plant Genome Research Unit, National Institute of Agrobiological Sciences (NIAS) \\ (Tsukuba, Ibaraki 305-8602, Japan)
}

\begin{abstract}
Ninety-nine recombinant inbred lines (RILs) were grown for three years and yield components were evaluated. Composite interval mapping showed that the vrs 1 and $u z u$ genes consistently controlled grain weight per plant. The analyses also identified a new QTL of kernel length on chromosome $3 \mathrm{H}$, a QTL for kernel width on chromosome $6 \mathrm{H}$ and a QTL for thousand-kernel weight on chromosome $2 \mathrm{H}$. The QTL generated in this study may be a useful target for marker-assisted selection in breeding programs.
\end{abstract}

Disciplines: Biotechnology / Plant breeding

Additional key words: composite interval mapping, dense spike (dspl), six-rowed spike (vrs 1), $u z u$ or semibrachytic (uzul)

\section{Introduction}

Oriental and occidental barley cultivars are genetically divergent from each other and they harbor genes characteristic of each region ${ }^{21}$. We developed recombinant inbred lines (RILs) from a cross between 'Azumamugi' and 'Kanto Nakate Gold'. Azumamugi was bred from a cross between two Japanese landraces ('Tochigi Sekitori 1' and 'Torano-o Sai 1'). Kanto Nakate Gold was bred by the following pedigree: Golden Melon/ Shikoku//Kinki Shu, where Golden Melon is a two-rowed erectum-type cultivar (origin Northern Europe), Shikoku is a Japanese landrace, and Kinki Shu is a selection from Golden Melon. Because Azumamugi and Kanto Nakate Gold belong to oriental and occidental cultivars respectively, the two genotypes are highly polymorphic for morphological, physiological, and molecular markers ${ }^{7,8,19}$. The objective of the present study is to identify QTLs for yield components, especially grain size in barley. We estimated genetic effects of known major genes and considered to detect new genes even with minor effects on these traits.

\section{Materials and methods}

Ninety-nine RILs $\left(\mathrm{F}_{12}\right.$ and $\left.\mathrm{F}_{13}\right)$ were developed from $\mathrm{F}_{2}$ plants of Azumamugi $\times$ Kanto Nakate Gold by single seed descent. Azumamugi is six-rowed (vrs 1.a), winter type (Sgh1/sgh2) and $u z u$ or semi-brachytic (uzul). Kanto Nakate Gold is two-rowed (Vrs1.b), spring type ( $\mathrm{sghl}$ / $\mathrm{Sgh2}$ ) and non-uzu (Uzul). Plants were sown in a field of NIAS, Tsukuba, in October 2000, 2001 and 2002, and grown until maturity in summer of 2001, 2002 and 2003 (thereafter referred to as 'Year 2001', 'Year 2002' and 'Year 2003', respectively). Each RIL was represented by a row of ten seeds and spaced $20 \mathrm{~cm}$ apart. Rows were spaced $80 \mathrm{~cm}$ apart. Four central plants of each RIL were harvested as a bundle of single plants, air-dried for one week at $30^{\circ} \mathrm{C}$, and used for measuring quantitative traits. For seed sizes, 10 seeds per RIL were measured using a projector Movias NAC 5200 (Image Technical Center, Yokohama, Japan).

The heritabilities $\left(\mathrm{h}^{2}\right)$ were estimated by the formula: $\mathrm{h}^{2}=\delta^{2}{ }_{\mathrm{g}} /\left(\delta^{2}{ }_{\mathrm{g}}+\delta^{2}{ }_{\mathrm{e}} / \mathrm{r}\right)$, where $\delta_{\mathrm{g}}^{2}=\left(\mathrm{MS}_{\text {genotype }}-\mathrm{MS}_{\text {error }}\right) / \mathrm{r}, \delta_{\mathrm{e}}^{2}$ $=\mathrm{MS}_{\text {error }}$ and $\mathrm{r}$ is number of replications. The correlation coefficients were computed using the computer program SPSS (Version 10.01, SPSS Corp., Chicago, IL).

Molecular linkage map ${ }^{11,12}$ and base map ${ }^{13}$ of these

*Corresponding author: e-mail takao@affrc.go.jp

Received 12 June 2006; accepted 26 October 2006. 
RILs were constructed previously. Map distances were estimated by using Kosambi's map function'. Composite interval mapping (CIM) was performed using the computer program QTL Cartographer ${ }^{2}$ version 1.14. A LOD score threshold of 3.0 was used to identify QTLs. The position of detected QTLs were compared with the ones of former QTL studies ${ }^{1,3,10,15}$ consulting integrated maps $^{6,16}$.

\section{Results and discussion}

RILs showed a wide range of variation for all the traits (Table 1). ANOVA showed that genetic variances for all the traits were significant, and heritability ranged from 0.73 to 0.99 (Table 2). Correlation coefficients between two years ranged from 0.61 to 0.98 , which were significant for all the traits (Table 3). Grain number per spike (GNS) and grain number per plant (GNP) were positively correlated with grain weight per plant $\left(\mathrm{GWT}_{\mathrm{g}}\right)$, but negatively correlated with thousand-kernel weight $\left(\mathrm{KWT}_{\mathrm{g}}\right.$ ) (Table 3).

GWT was controlled predominantly by $v r s 1$ and $u z u$ as detected previously ${ }^{3,5,15,23}$. The allele of Azumamugi at the vrs 1 locus increased GWT by $9.15-11.75 \mathrm{~g}$ (Table 4). KWT of six-rowed lines was $74 \%$ of two-rowed lines, but GNP of six-rowed lines was 2.7 times of two-rowed lines, therefore GWT of six-rowed lines was 1.5 times of tworowed lines, showing six-rowed lines have a potential of higher yield than two-rowed lines (Fig. 1). The allele of Azumamugi at the $u z u$ locus decreased GWT by 9.9-10 g (Table 4). However, the $u z u$ locus did not control the GNP. Another QTL for GWT was detected on chromo-

Table 1. Means, coefficient of variations and standard deviations for agronomic traits observed in Azumamugi, Kanto Nakate Gold and their 99 RILs

\begin{tabular}{|c|c|c|c|c|c|c|c|c|c|c|}
\hline Traits & $\begin{array}{c}\text { GWT } \\
(\mathrm{g})\end{array}$ & $\begin{array}{c}\text { STW } \\
(\mathrm{g})\end{array}$ & $\begin{array}{c}\text { HI } \\
(\%)\end{array}$ & $\begin{array}{l}\text { KLN } \\
(\mathrm{mm})\end{array}$ & $\begin{array}{l}\text { KWD } \\
(\mathrm{mm})\end{array}$ & $\mathrm{KS}$ & $\begin{array}{c}\mathrm{KA} \\
\left(\mathrm{mm}^{2}\right)\end{array}$ & GNS & GNP & $\begin{array}{c}\text { KWT } \\
\text { (g) }\end{array}$ \\
\hline \multicolumn{11}{|l|}{ Year 2002} \\
\hline Azumamugi & 61.3 & 52.3 & 53.9 & 7.5 & 3.4 & 2.3 & 25.1 & 92.1 & 1,953 & 35.2 \\
\hline Kanto Nakate Gold & 80.0 & 106.3 & 43.0 & 10.0 & 3.8 & 2.7 & 37.3 & 39.0 & 1,278 & 53.0 \\
\hline RIL - mean & 54.9 & 70.9 & 43.1 & 8.6 & 3.5 & 2.5 & 29.9 & 66.4 & 1,864 & 38.5 \\
\hline $\mathrm{RIL}-\mathrm{SD}^{1)}$ & 22.5 & 24.6 & 9.5 & 0.7 & 0.3 & 0.3 & 3.5 & 30.2 & 905 & 7.3 \\
\hline RIL - minimum & 12.5 & 25.0 & 18.8 & 7.1 & 3.0 & 1.8 & 22.9 & 25.8 & 399 & 24.4 \\
\hline RIL - maximum & 117.5 & 145.0 & 62.5 & 10.4 & 4.2 & 3.5 & 37.4 & 108.0 & 3,933 & 54.4 \\
\hline $\mathrm{RIL}-\mathrm{CV}^{2)}$ & 41.0 & 34.6 & 22.1 & 8.5 & 7.6 & 11.1 & 11.6 & 45.5 & 48.6 & 18.9 \\
\hline \multicolumn{11}{|l|}{ Year $2003^{3)}$} \\
\hline Azumamugi & 50.0 & 25.0 & 66.7 & 7.6 & 3.3 & 2.3 & 25.2 & 96.0 & 3,192 & 34.0 \\
\hline Kanto Nakate Gold & 47.5 & 46.3 & 50.7 & 9.9 & 3.7 & 2.7 & 36.6 & 36.0 & 1,593 & 49.6 \\
\hline RIL - mean & 43.1 & 57.4 & 42.3 & 8.2 & 3.6 & 2.3 & 29.6 & 62.1 & 1,759 & 33.4 \\
\hline $\mathrm{RIL}-\mathrm{SD}$ & 17.6 & 17.6 & 10.8 & 0.7 & 0.2 & 0.2 & 3.6 & 27.5 & 826 & 6.9 \\
\hline RIL - minimum & 6.3 & 20.0 & 10.4 & 6.8 & 3.0 & 1.8 & 22.4 & 21.0 & 578 & 18.0 \\
\hline RIL - maximum & 87.5 & 127.5 & 61.9 & 9.9 & 4.2 & 3.4 & 37.2 & 105.0 & 3,600 & 47.6 \\
\hline $\mathrm{RIL}-\mathrm{CV}$ & 40.9 & 30.6 & 25.5 & 8.6 & 6.7 & 10.5 & 12.0 & 44.3 & 47.0 & 20.8 \\
\hline
\end{tabular}

1): Standard deviation.

2): Coefficient of Variation (\%).

3): Data in italic were scored in the Year 2001.

Table 2. Analysis of variance for agronomic traits in the RILs from the cross of Azumamugi $\times$ Kanto Nakate Gold

\begin{tabular}{lrcccccccccc}
\hline \hline Source & df & GWT & \multicolumn{1}{l}{ STW } & HI & KLN & KWD & KS & KA & GNS & GNP & KWT \\
\hline Genotype & 98 & $693.67^{* *}$ & $721.08^{* *}$ & $178.19^{* *}$ & $0.93^{* *}$ & $0.11^{* *}$ & $0.12^{* *}$ & $21.04^{* *}$ & $1,647.30^{* *}$ & $1,406,931.00^{* *}$ & $95.70^{* *}$ \\
Year & 1 & $6,913.64^{* *}$ & $9,102.58^{* *}$ & $35.33 \mathrm{~ns}$ & $7.18^{* *}$ & $0.68^{* *}$ & $1.53^{* *}$ & $5.33 \mathrm{~ns}$ & $932.75^{* *}$ & $540,248.70^{*}$ & $1,311.57^{* *}$ \\
Error & 98 & 124.40 & 191.11 & 29.00 & 0.10 & 0.02 & 0.01 & 3.74 & 20.98 & $95,717.71$ & 5.57 \\
\hline Heritability & 0.82 & 0.73 & 0.84 & 0.89 & 0.82 & 0.90 & 0.82 & 0.99 & 0.93 & 0.94 \\
\hline
\end{tabular}

$*, * *$ : significant at the $5 \%$ and $1 \%$ level respectively.

ns: not significant. 
Table 3. Correlation coefficients between agronomic traits in the RILs (Year 2002)

\begin{tabular}{|c|c|c|c|c|c|c|c|c|c|c|}
\hline & GWT & STW & $\mathrm{HI}$ & KLN & KWD & $\mathrm{KS}$ & KA & GNS & GNP & KWT \\
\hline GWT & $\underline{0.717 * *}$ & & & & & & & & & \\
\hline STW & $0.530 * *$ & $\underline{0.614 * *}$ & & & & & & & & \\
\hline HI & $0.620 * *$ & $-0.281 * *$ & $\underline{0.726^{* *}}$ & & & & & & & \\
\hline KLN & $0.279 * *$ & $0.504 * *$ & -0.150 & $\underline{0.805 * *}$ & & & & & & \\
\hline KWD & $-0.376^{* *}$ & 0.093 & $-0.488 * *$ & 0.047 & $\underline{0.688^{* *}}$ & & & & & \\
\hline $\mathrm{KS}$ & $0.485^{* *}$ & $0.333 * *$ & $0.221^{*}$ & $0.724 * *$ & $-0.649 * *$ & $\underline{0.830 * *}$ & & & & \\
\hline KA & -0.057 & $0.418^{* *}$ & $-0.433 * *$ & $0.752 * *$ & $0.691 * *$ & 0.091 & $\underline{0.698 * *}$ & & & \\
\hline GNS & $0.476 * *$ & -0.189 & $0.700 * *$ & $-0.256^{* *}$ & $-0.688^{* *}$ & $0.283 * *$ & $-0.644 * *$ & $\underline{0.979 * *}$ & & \\
\hline GNP & $0.701 * *$ & 0.100 & $0.668 * *$ & -0.067 & $-0.681 * *$ & $0.429 * *$ & $-0.508 * *$ & $0.903 * *$ & $\underline{0.876^{* *}}$ & \\
\hline KWT & $-0.208^{*}$ & $0.293 * *$ & $-0.455^{* *}$ & $0.422 * *$ & $0.732 * *$ & -0.189 & $0.794 * *$ & $-0.814^{* *}$ & $-0.722 * *$ & $\underline{0.891 * *}$ \\
\hline
\end{tabular}

***: significant at the $5 \%$ and $1 \%$ level respectively. Correlation coefficients between two years are underlined.

some 3HL, but it may coincide with denso $(s d w 1)^{3,6,16}$.

The major factor of GNP, GNS and KWT was the vrs1 locus (Table 4). Six-rowed lines decrease KWT but considerably increase GNP, thus six-rowed spikes increase the yield of grains (Fig. 1). The vrs 1 locus contributed 25 to $80 \%$ of phenotypic variance for KWT in separate studies $^{1,4,5,14,24}$ and $63-72 \%$ in this study. In spite of the major effect by the vrs 1 locus on KWT, we detected a new QTL for KWT named $q K W T . a k-2 H$ on the short arm of chromosome $2 \mathrm{H}$ (Table 4). The allele of Azumamugi at this QTL increased KWT.

The $v r s 1, u z u$ and $d s p 1$ have been reported to control the kernel sizes ${ }^{1,20}$ and our result was in agreement with these reports. Behind the pronounced effects of these major genes, we detected a new QTL for kernel length $\left(\mathrm{KLN}_{\mathrm{mm}}\right)$ named $q K L N . a k-3 H$ on chromosome $3 \mathrm{HS}$ and a new QTL for kernel width $\left(\mathrm{KWD}_{\mathrm{mm}}\right)$ named $q K W D . a k$ $6 H$ on chromosome $6 \mathrm{H}$ (Table 4). The QTL of KWD detected on chromosome $7 \mathrm{H}$ can be identical with $q D H E$. $a k-7 H$, which controlled days to heading ${ }^{18}$. Kernel shape (KS $=\mathrm{KLN} / \mathrm{KWD}$ ) was controlled by $v r s 1, u z u$ and $d s p 1$, but kernel area $\left(\mathrm{KA}_{\mathrm{mm}}{ }^{2}=\mathrm{KLN}_{\mathrm{mm}} \times \mathrm{KWD}_{\mathrm{mm}}\right)$ was controlled by vrs 1 and $u z u$.

QTL for straw weight per plant $\left(\mathrm{STW}_{\mathrm{g}}\right)$ was detected on chromosome $3 \mathrm{HL}$, at the $u z u$ locus, and the allele of Azumamugi decreased STW by 6-11.8 g (Table 4). Another QTL for STW was detected on chromosome 3HL (may coincide with denso), together with Ppd-H1 (Eam1) and Sgh2 (spring growth habit ${ }^{22}$ ), which primarily controlled days to heading ${ }^{10,17}$. The QTL of harvest index $\left(\mathrm{HI}_{\%}=100 \times \mathrm{GWT} /(\mathrm{GWT}+\mathrm{STW})\right)$ detected on chromosome $5 \mathrm{HL}$ could correspond to $q T P N . a k-5 H$, which was a QTL for triplet number ${ }^{18}$.

Our study detected new QTLs for controlling seed size. These QTLs are useful for modifying spike architecture moderately rather than the major genes of strong pleiotrophic effects. The QTLs may be introduced to cul-
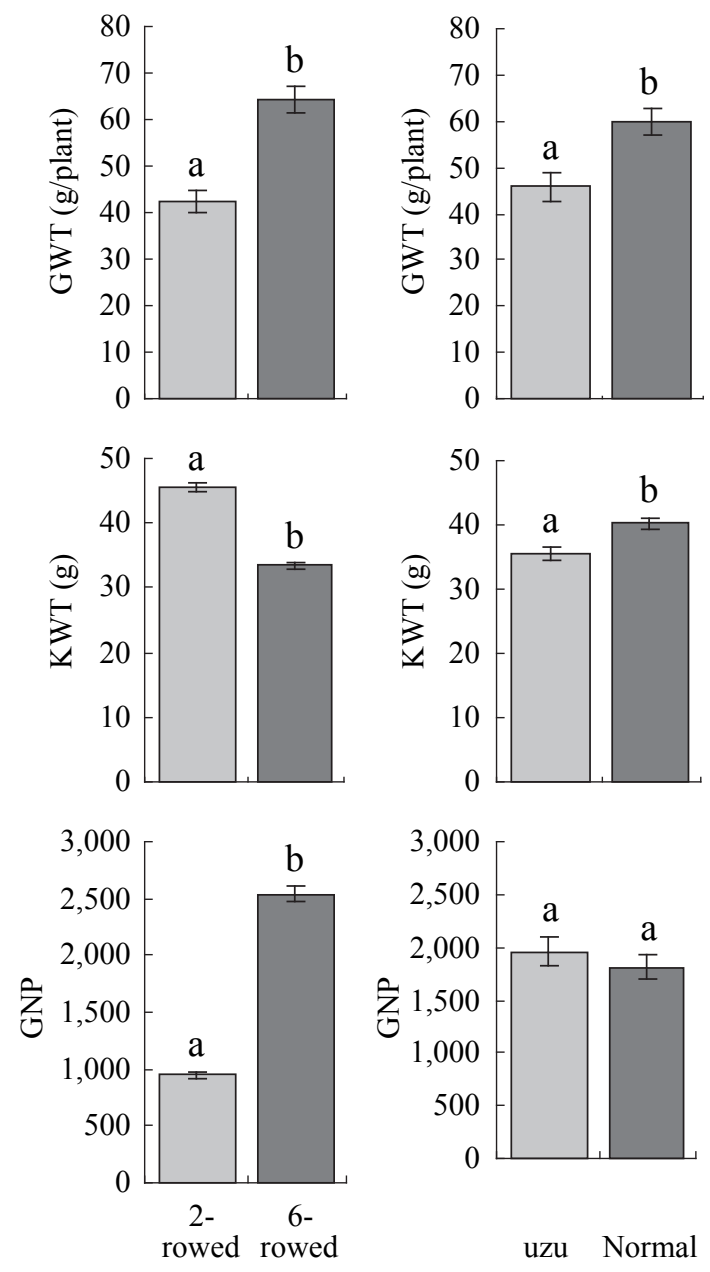

Fig. 1. Effects of the six-rowed spike gene (vrs1) and uzu gene on grain weight per plant (GWT), grain number per plant (GNP) and thousand-kernel weight (KWT) for 'Year 2002'.

Error bars represent standard error. Any two means having a common letter are not significantly different at the $5 \%$ level of significance in the Student's $t$ test distribution. 


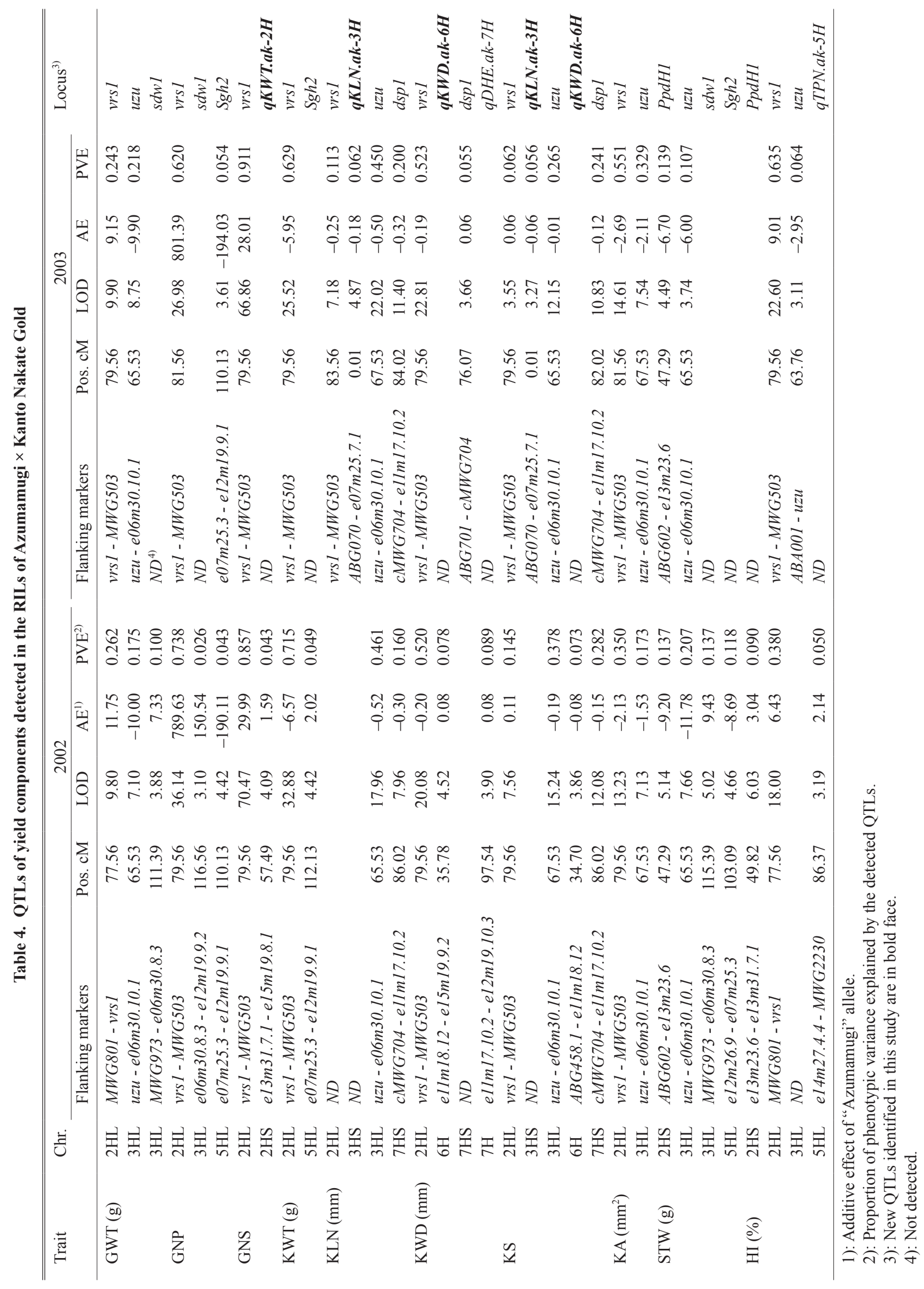


tivars by means of marker-assisted selection in breeding programs.

\section{Acknowledgments}

We thank Kayoko Muromachi for her help in the field evaluations. Research grants from the Ministry of Agriculture, Forestry and Fisheries of Japan (MAFF) and Japan Science and Technology Corporation (JST) are gratefully appreciated.

\section{References}

1. Ayoub, M. et al. (2002) QTLs affecting kernel size and shape in a two-rowed by six-rowed barley cross. Theor. Appl. Genet., 105, 237-247.

2. Basten, C. J., Weir, B. S. \& Zeng, Z. B. (2000) QTL Cartographer, Version 1.14. Department of Statistics, North Carolina State University, Raleigh, North Carolina, USA.

3. Hayes, P. M. et al. (1993) Quantitative trait locus effects and environmental interaction in a sample of North American barley germplasm. Theor. Appl. Genet., 87, 392-401.

4. Kicherer, S. et al. (2000) Localising QTLs for leaf rust resistance and agronomic traits in barley (Hordeum vulgare L.). Theor. Appl. Genet., 100, 881-888.

5. Kjaer, B. \& Jensen, J. (1996) Quantitative trait loci for grain yield and yield components in a cross between a sixrowed and a two-rowed barley. Euphytica, 90, 39-48.

6. Kleinhofs, A. (2002) Integrating molecular and morphological/physiological marker maps. Barley Genet. Newsl., 32, 152-159.

7. Komatsuda, T., Annaka, T. \& Oka, S. (1993) Genetic mapping of a quantitative trait locus (QTL) that enhances the shoot differentiation rate in Hordeum vulgare L. Theor. Appl. Genet., 86, 713-720.

8. Komatsuda, T. et al. (1998) Development of STS markers closely linked to the vrs 1 locus in barley, Hordeum vulgare. Genome, 41, 680-685.

9. Kosambi, D. D. (1944) The estimation of map distance from recombination values. Ann. Eugen., 12, 172-175.

10. Laurie, D. A. et al. (1995) RFLP mapping of five major genes and eight quantitative trait loci controlling flowering time in a winter $\times$ spring barley (Hordeum vulgare $\mathrm{L}$.) cross. Genome, 38, 575-585.

11. Mano, Y. et al. (1999) Map construction of sequencetagged sites (STSs) in barley (Hordeum vulgare L.). Theor. Appl. Genet., 98, 937-946.

12. Mano, Y. et al. (2001) Construction of a genetic map of barley (Hordeum vulgare L.) cross 'Azumamugi' × 'Kanto
Nakate Gold' using a simple and efficient amplified fragment-length polymorphism system. Genome, 44, 284-292.

13. Mano, Y. \& Komatsuda, T. (2002) Identification of QTLs controlling tissue-culture traits in barley (Hordeum vulgare L.). Theor. Appl. Genet., 105, 708-715.

14. Marquez-Cedillo, L. A. et al. (2000) QTL analysis of malting quality in barley based on the doubled-haploid progeny of two elite North American varieties representing different germplasm groups. Theor. Appl. Genet., 101, 173-184.

15. Marquez-Cedillo, L. A. et al. (2001) QTL analysis of agronomic traits in barley based on the doubled haploid progeny of two elite North American varieties representing different germplasm groups. Theor. Appl. Genet., 103, 625-637.

16. Qi, X., Stam, P. \& Lindhout, P. (1996) Comparison and integration of four barley genetic maps. Genome, $\mathbf{3 9}$, 379-394.

17. Sameri, M. \& Komatsuda, T. (2004) Identification of quantitative trait loci (QTLs) controlling heading time in the population generated from a cross between oriental and occidental barley cultivars (Hordeum vulgare L.). Breed. Sci., 54, 327-332.

18. Sameri, M., Takeda, K. \& Komatsuda, T. (2006) Quantitative trait loci controlling agronomic traits in recombinant inbred lines from a cross between orientaland occidental-type barley cultivars. Breed. Sci., 56, 243-252.

19. Sayed-Tabatabaei, B. E. et al. (1999) Sequence-tagged sites for barley genome mapping. Bull. Natl. Inst. Agrobiol. Resour., 13, 11-22.

20. Takahashi, R. (1951) Studies on the classification and geographical distribution of the Japanese barley varieties. II. Correlative inheritance of some quantitative characters with the ear type. Ber. Ohara Inst. Landw. Forsch., 9, 383-398.

21. Takahashi, R. (1955) The origin and evolution of cultivated barley. In Advances in genetics 7, ed. Demerec, M., Academic Press, New York, 227-266.

22. Takahashi, R. \& Yasuda, S. (1956) Genetic studies of spring and winter habit of growth in barley. Ber. Ohara Inst. Landw. Biol. Okayama Univ., 10, 245-308.

23. Takahashi, R., Hayashi, J. \& Moriya, I. (1963) The effect of the $u z u$ gene on productive traits in barley. I. Evaluation of the genetic effects in different genetic backgrounds. Ber. Ohara Inst. Landw. Biol. Okayama Univ., 12, 24-42.

24. Takahashi, R., Hayashi, J. \& Moriya, I. (1975) Studies on barley breeding with two-rowed and six-rowed varietal crosses. I. Effects of the genes $V$ and $v$ on agronomic characters. Jpn. J. Breed., 25, 334-342 [In Japanese with English summary]. 